\title{
JUSTIFICATION OF STRENGTHENING A SLIDING BRIDGE SUPPORT (ON THE EXAMPLE OF THE BRIDGE THROUGH THE R. IZHORA ON THE HIGH-SPEED ROAD SAINT PETERSBURG - MOSCOW)
}

\author{
Rashid A. Mangushev ${ }^{1}$, Nadezhda S. Nikitina ${ }^{2}$, Anatolii I. Osokin ${ }^{1}$, \\ Maria B. Zavodchikova ${ }^{1}$, Viacheslav M. Polunin ${ }^{1}$ \\ ${ }^{1}$ Saint-Petersburg State Architecture and Construction University, Saint-Petersburg, RUSSIA \\ ${ }^{2}$ National Research Moscow State University of Civil Engineering, Moscow, RUSSIA
}

\begin{abstract}
The article describes the experience of strengthening the foundations of the bridge support laying on a landslide slope. The bridge under consideration crosses the river Izhora in the Leningrad region. Numerical modeling of the process of development of support deformations is carried out. Analysis of the calculations showed that the development of the landslide process occurred as a result of waterlogging of the soil massif and soaking of soils at the base of support No. 10. Structural strengthening of the support in the form of buttresses was developed and numerically substantiated to eliminate deformation of the bridge support.
\end{abstract}

Keywords: deformations of bridge support, landslide slope, numerical modeling, strengthening with buttress

\section{ОБОСНОВАНИЕ УСИЛЕНИЯ СПОЛЗАЮЩЕЙ МОСТОВОЙ ОПОРЫ (НА ПРИМЕРЕ МОСТА ЧЕРЕЗ Р. ИЖОРУ НА СКОРОСТНОЙ АВТОМОБИЛЬНОЙ ДОРОГЕ САНКТ-ПЕТЕРБУРГ - МОСКВА)}

\author{
Р.А. Мангушев ${ }^{1}$ Н.С. Никитина ${ }^{2}$, А.И. Осокин ${ }^{1}$, М.Б. Заводчикова ${ }^{1}$, В.М. Полунин ${ }^{1}$ \\ ${ }^{1}$ Санкт-Петербургский государственный архитектурно-строительный университет, \\ г. Санкт-Петербург, РОССИЯ \\ ${ }^{2}$ Национальный исследовательский Московский государственный строительный университет, \\ г. Москва, РОССИЯ
}

\begin{abstract}
Аннотация: В статье приведен опыт усиления фундаментов опоры моста в Ленинградской области через p. Ижора на оползневом склоне. Выполнено численное моделирование процесса развития деформаций опоры. Анализ расчетов показал, что развитие оползневого процесса произошло в результате переувлажнения грунтового массива и замачивания грунтов в основании опоры №10. Было разработано и численным методом обосновано конструктивное усиление опоры в виде контрфорсов для исключения деформирование опоры моста.
\end{abstract}

Ключевые слова: деформации опоры моста, оползневой склон, численное моделирование, усиление в виде контрфорсов

\section{INTRODUCTION}

During the period from November 2019 to February 2020 a geotechnical monitoring of the section of the Moscow - St. Petersburg highspeed highway in the area of the bridge over the river. Izhora (PK 6334) had been conducted. The geotechnical monitoring shown uneven 
deformations on support No 10L. The average rate of horizontal deformations of support No. 10L, according to geodetic observations, was up to 1.0 mm per day. As a result, it was necessary to develop recommendations for stabilizing the settlement to the axis of the track were $93 \mathrm{~mm}$ along the point. Figure 3 shows the layout of the marks and the measured displacement values.

The main deformations were noted in the inclinometric well No. 5, installed in the immediate

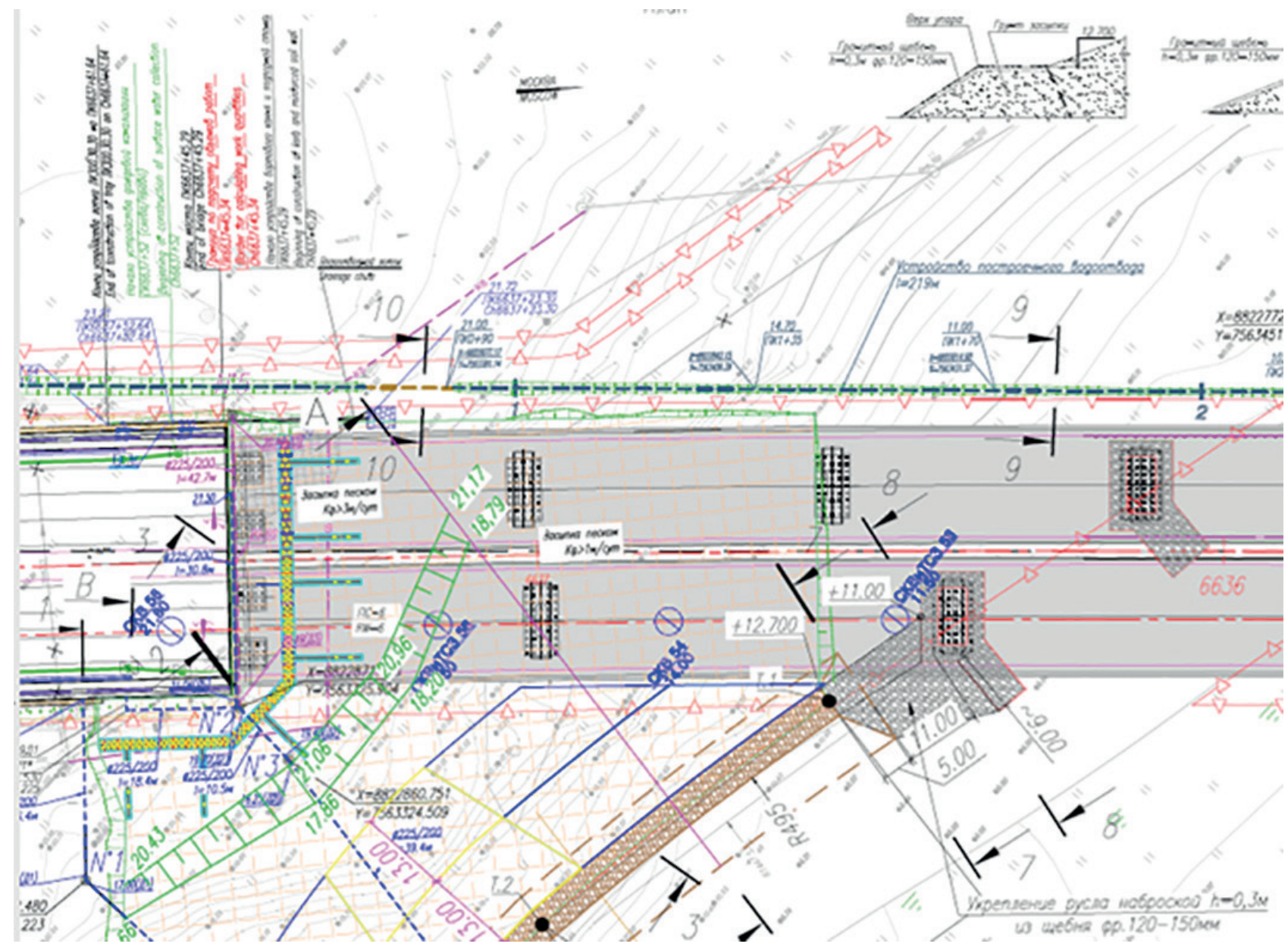

Figure 1. Location plan of the object of geotechnical analysis - support No. 10L

of the specified support, taking into account the projected structures of its strengthening.

The site is located on the left high bank of the river. Izhora. The relief of the site is characterized by the presence of a steep slope to the river. Izhora, located $15.0 \mathrm{~m}$ south of the site of additional surveys. The bridge supports are located on the not reinforced slope.

According to the monitoring results from 03.02.2020, the maximum horizontal displacements of the support parallel to the axis of the track were $148 \mathrm{~mm}$, the horizontal deviations perpendicular

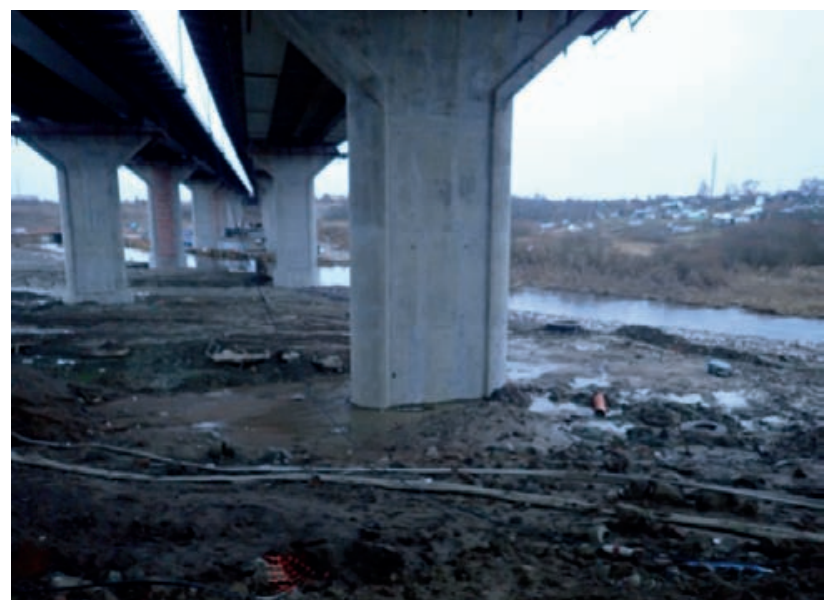

Figure 2. Actual situation at support No. $10 \mathrm{~L}$ 